Kyle Capistrant-Fossa* and Susan H. Brawley

\title{
Unexpected reproductive traits of Grateloupia turuturu revealed by its resistance to bleach- based biosecurity protocols
}

https://doi.org/10.1515/bot-2018-0104

Received 28 November, 2018; accepted 21 February, 2019; online first 15 March, 2019

Abstract: A non-indigenous alga, Grateloupia turuturu (Halymeniales, Rhodophyta), was discovered in the Damariscotta Estuary (Maine, USA) in 2017, over $200 \mathrm{~km}$ north of its last reported location. Because of the presence of coastal facilities (aquaculture, marine laboratories) among potential vectors, we evaluated a mandated biosecurity protocol, namely, seawater treated with bleach at $50 \mathrm{ppm}\left(50 \mathrm{mg} \mathrm{l}^{-1}\right)$ free chlorine for $\geq 2 \mathrm{~h}$ and measured using test strips, for lethality against $G$. turuturu and several native algae. We report unexpected resilience to bleach-treatment (Mastocarpus $>$ Grateloupia $>$ Palmaria). Holdfasts of G. turuturu and Mastocarpus stellatus survived 50 and 1000 ppm free chlorine, respectively. Cystocarps on cultured blades of G. turuturu were particularly resistant to bleach-treatment; they produced outgrowths on fragmenting blades that became fertile tetrasporophytes in culture, suggesting reproductive adaptations of cystocarps to stressful conditions that may have broader evolutionary significance. Juvenile, microscopic crusts of G. turuturu were also bleachresistant if covered by diatoms, and developed upright axes. Free chlorine test strips were inaccurate in seawater, and their use could increase the risk of failed biosecurity as a vector for invasion. Because chlorination at economic and environmentally safe levels is insufficient, we recommend a combination of treatments for comprehensive biosecurity.

Keywords: free chlorine measurement; heat-treatment; hypochlorite; non-indigenous species; red algae.

\footnotetext{
*Corresponding author: Kyle Capistrant-Fossa, School of Marine Sciences, University of Maine, 5735 Hitchner Hall, Orono, ME 04469-5735, USA, e-mail: kyle.capistrantfossa@maine.edu. https://orcid.org/0000-0003-1159-4556

Susan H. Brawley: School of Marine Sciences, University of Maine, 5735 Hitchner Hall, Orono, ME 04469-5735, USA. https://orcid. org/0000-0002-6444-5290
}

\section{Introduction}

Global transportation networks have resulted in large numbers of non-indigenous species (NIS) appearing in marine ecosystems. Major vectors of introduction include the aquarium and ornamental trades (Williams et al. 2015, Vranken et al. 2018), ballast water (Carlton and Geller 1993), biofouling on commercial ships (Williams et al. 2013, Lacoursière-Roussel et al. 2016, Whitman Miller et al. 2018), transport with shellfish (Hégaret et al. 2008), and transoceanic transport after natural disasters (Carlton et al. 2018, Hanyuda et al. 2018). A common invader is Grateloupia turuturu Yamada, a low to subtidal red alga originally described from Japan (Yamada 1941) that now has a nearly global distribution after primary and secondary introductions (e.g. Marston and Villalard-Bohnsack 2002, Verlaque et al. 2005, Saunders and Withall 2006, D’Archino et al. 2007, Bolton et al. 2016, Brodie et al. 2016). Following introduction to the Northwestern Atlantic (Rhode Island) in 1994 (Villalard-Bohnsack and Harlin 1997, Gavio and Fredericq 2002, Marston and Villalard-Bohnsack 2002), G. turuturu spread north into the Gulf of Maine (Figure 1) and south into Long Island Sound (Mathieson et al. 2008, Macroalgal Herbarium Consortium 2018). The spread of G. turuturu was likely enhanced because it is eurythermal $\left(4-28^{\circ} \mathrm{C}\right)$, euryhaline (salinities 12-52), and exhibits rapid growth in eutrophic coastal habitats often associated with invasion vectors (Simon et al. 1999, 2001). Grateloupia turuturu shares many traits of other highly invasive species, but it was considered less hazardous under one major scoring criterion ("establishment") used by Nyberg and Wallentinus (2005), apparently due to its palatability and lack of vegetative reproduction and fragmentation; still, these investigators ranked risk from $G$. turuturu as fifth highest out of 113 invasive marine macroalgae.

Many governmental and commercial entities have adopted biosecurity measures to curb the spread of pathogens or exotic species like Grateloupia turuturu. After experimental work to investigate biosecurity, chlorine bleach remains commonly used (e.g. Williams and Schoeder 2004, Fukuzaki 2006, Odom and Walters 2015). For example, the Maine Department of Marine Resources 


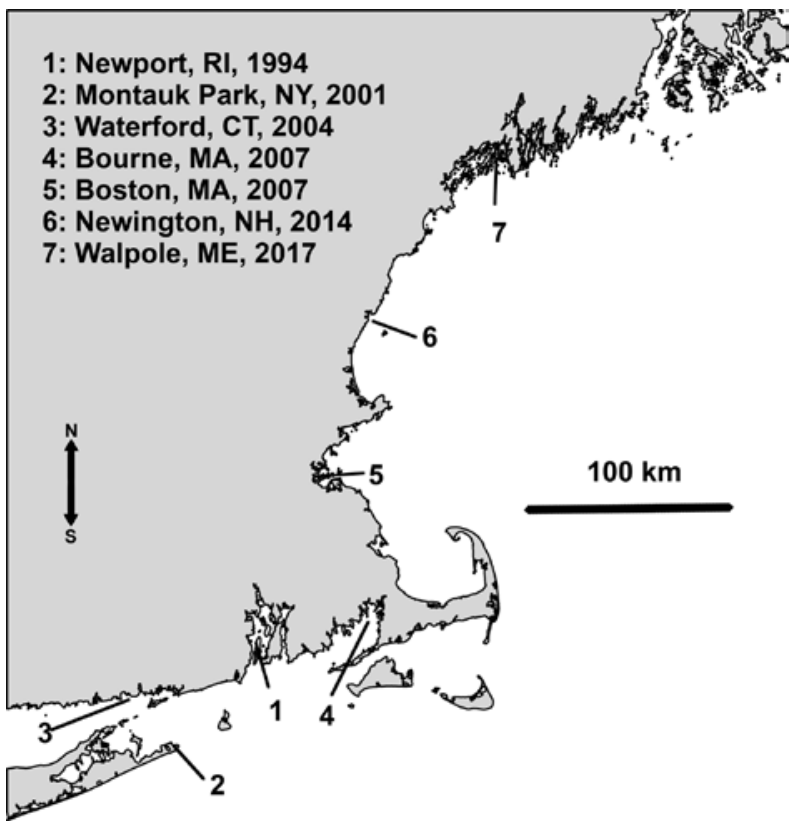

Figure 1: Spread of Grateloupia turuturu along the New England coast from 1994 to 2017.

(DMR) requires that wastewater from shellfish broodstock be disinfected in at least a $50 \mathrm{ppm}\left(50 \mathrm{mg} \mathrm{l}^{-1}\right)$ concentration of free chlorine from bleach for at least $2 \mathrm{~h}$ (Maine Department of Marine Resources 2019). A 50 ppm free chlorine solution was also recommended to destroy bacterial films in aquaculture (OIE 2009). Managers and regulators dealing with water quality use the term "free chlorine" to refer to either hypochlorous acid ( $\mathrm{HOCl}$ ) or hypochlorite ion $\left(\mathrm{OCl}^{-}\right)$. Bleach (sodium hypochlorite) is a strong oxidizing agent that damages cells and molecules in multiple ways including reactive oxygen stress (ROS; Fukuzaki 2006). As part of investigating the invasion of $G$. turuturu along the Maine coast, we examined the effects of bleach on the invader and a range of native algae, as well as considering the effectiveness of heat (Williams and Schoeder 2004, Forrest and Blakemore 2006) as a safe alternative to bleach. Here, we show that G. turuturu and several other macroalgae are highly resistant to the standard bleach protocol, and we report a novel outcome of bleach-treatment on G. turuturu that leads to new growth and fragmentation, which might contribute to its invasiveness.

\section{Materials and methods}

\section{Standard culture conditions and definitions}

Field-collected blades and blades cultured before and after experiments were placed under the following conditions, unless stated otherwise: $12^{\circ} \mathrm{C}$, $14: 10$ (L:D), $50 \mu \mathrm{mol}$ photons $\mathrm{m}^{-2} \mathrm{~s}^{-1}$ (Phillips T8 fluorescent tubes, Eindhoven, the Netherlands), and nutrient-enriched sterile seawater (West-McBride nutrient solution, Andersen 2005). Water motion and aeration were provided by bubbling containers with air using aquarium pumps. The lengths of recovery periods mentioned below were those determined to encompass new development and growth or to continue until remaining tissue disintegrated under standard culture conditions. Media were changed at least weekly. "Seawater" refers to sterile seawater from the Maine coast, obtained from UV-treated and 0.2- $\mu \mathrm{m}$-filtered seawater supplied by the University of Maine's Center for Cooperative Aquaculture Research (Franklin, ME, USA). "Bleach" refers to Hannaford's Regular Bleach (Hannaford Bros Co., Scarborough, ME, USA).

\section{Field surveys and verification of Grateloupia turuturu}

Eight surveys (22 Sept 2017, 2 Oct 2017, 30 Nov 2017, 14 Feb 2018, 9 April 2018, 14 May 2018, 9 July 2018, 7 Aug 2018) were made on the shore at the University of Maine's Darling Marine Center (DMC) on the Damariscotta Estuary in Walpole, Maine $\left(43.936176^{\circ} \mathrm{N}, 69.581214^{\circ} \mathrm{W}\right)$. Additional surveys of the estuary were performed by Maine's Department of Marine Resources (6 Sept 2018) and the first author (1 Oct 2018). Any alga resembling Grateloupia turuturu was collected for identification and determination of reproductive condition. DNA was extracted from wild plants (Oct 2017) and from new blades that emerged from cystocarps of experimental, bleach-treated blades using a DNeasy Plant MiniKit (Qiagen, Germantown, MD, USA). The $r b c \mathrm{~L}$ gene was amplified from position 57 to 753 using primers (Freshwater and Rueness 1994) F57 (5'-GTAATTCCATATGCTAAAATGGG) and R753 (5'-GCTCTTTCATACATATCTTCC) with Phusion High Fidelity DNA polymerase (New England Biolabs, Ipswich, MA, USA) through PCR $\left(98^{\circ} \mathrm{C}\right.$ for $30 \mathrm{~s}$, $\left[98^{\circ} \mathrm{C}\right.$ for $7 \mathrm{~s}, 58^{\circ} \mathrm{C}$ for $10 \mathrm{~s}, 72^{\circ} \mathrm{C}$ for $\left.15 \mathrm{~s}\right] \times 30,72^{\circ} \mathrm{C}$ for $5 \mathrm{~min}$ ). PCR products were purified using a QIAquick PCR Purification Kit (Qiagen, Germantown, MD, USA), sequenced (University of Maine DNA Sequencing Facility), and analyzed with BLASTN (www.ncbi.nlm.nih.gov).

\section{Determining free chlorine in seawater}

\section{lodometric titration protocol}

We adapted a protocol from one provided by OxyChem (Occidental Chemical Corporation 2014). First, $25 \mathrm{ml}$ of 
experimental sample (seawater or seawater + bleach) was weighed and diluted to a final volume of $250 \mathrm{ml}$ in deionized water (Millipore Gradient A10 system, St. Louis, USA). After mixing, a 10-ml aliquot was placed into a beaker containing $50 \mathrm{ml}$ deionized water, and then $25 \mathrm{ml} \mathrm{10 \%}$ potassium iodine, $10 \mathrm{ml} \mathrm{50 \%}$ acetic acid, and $5 \mathrm{ml}$ starch indicator (\#SS408-1, Fisher, Fair Lawn, NJ, USA) were added and the solution was mixed thoroughly. At this point, test solutions were purple to black in color. Then, $0.01 \mathrm{~N}$ sodium thiosulfate was added drop-wise using a pipette while mixing the solution after each addition. The total volume of sodium thiosulfate needed to make the solution colorless (transparent) was recorded. To determine the free chlorine concentration (\%), we used the following equation (Occidental Chemical Company 2014) where $\mathrm{V}$ is the volume of sodium thiosulfate added, 0.01 is the normality of the sodium thiosulfate, 0.03722 is the milliequivalent weight of $\mathrm{NaOCl}, 0.04$ is the dilution factor, and $\mathrm{W}$ is the mass of the sample:

$$
\% \mathrm{NaOCl}=\frac{(\mathrm{V})(0.01)(0.03722)(100)}{(0.04)(\mathrm{W})}
$$

\section{Comparison of test strips vs. iodometric titration}

We compared the apparent free chlorine concentration in a seawater solution as determined by either high-range free chlorine test strips or iodometric titration. Solutions produced by calculation of the amount of bleach required

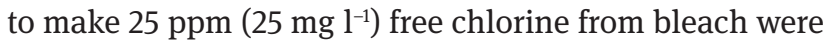
made in a series of deionized water dilutions of seawater of 0\%, 25\%, 50\%, 75\%, and 100\% seawater. A 25-ml aliquot was taken from each sample and measured in duplicate though iodometric titration. The free chlorine concentrations of the solutions were also measured using high-range free chlorine test strips (HACH \#2890200, Loveland, CO, USA; or LaMotte \#3031, Chestertown, MD, USA), because these are in common use for this purpose on the Maine coast in aquaculture facilities and other laboratories. The $\mathrm{pH}$ of the solutions was determined (Accumet AB200 pH meter, Fair Lawn, USA).

\section{Verification of bromine interference in test strip determinations}

To demonstrate the degree of bromine interference in a high chloride solution (i.e. seawater, Bousher et al. 1986) during free chlorine determination with test strips (HACH \#2890200, Loveland, CO, USA), we produced a series of solutions to mimic this interaction with $\mathrm{NaCl}$ and $\mathrm{NaBr}$ that reflect seawater $\mathrm{Cl}^{-}$and $\mathrm{Br}^{-}$. Bleach was added to 11 of the following solutions by calculation to provide $50 \mathrm{ppm}$ free chlorine solution: (1) deionized water, (2) $0.6 \mathrm{~mm}$ $\mathrm{NaBr}$, (3) $0.45 \mathrm{M} \mathrm{NaCl}$, (4) $0.6 \mathrm{~mm} \mathrm{NaBr}+0.45 \mathrm{M} \mathrm{NaCl}$, and (5) sterile seawater from the Maine coast.

\section{Exploring the effects of free chlorine on Grateloupia turuturu and native red algae}

\section{Cultured blades of Grateloupia turuturu}

Two blades of Grateloupia turuturu were cultured from a collection made 14 Feb 2018 on the DMC shore. One blade was cultured under standard conditions without exposure to bleach (vegetative; "A"), and a second cystocarpic blade was exposed twice for $2 \mathrm{~h}$ with 50 ppm free chlorine from bleach (cystocarpic; "B”; Treatment 1: 16 March 2018; Treatment 2: 9 Apr 2018) without damage in either of these preliminary experiments and subsequently cultured under standard conditions. On 7 May 2018, Blade "A" was placed into 31 of seawater containing 50 ppm free chlorine prepared from bleach for $4 \mathrm{~h}$ under standard culture conditions, before the concentration was increased to $75 \mathrm{ppm}$ for an additional $2 \mathrm{~h}$. Blade "B" was placed into 31 of $100 \mathrm{ppm}$ free chlorine for $4 \mathrm{~h}$. After being rinsed with sterile seawater, blades were put into culture, individually, under standard culture conditions.

\section{Comparison between effects of sodium hypochlorite versus commercial bleach}

Blades of Grateloupia turuturu of similar size were collected on 9 July 2018 , kept on ice $\left(4^{\circ} \mathrm{C}\right)$ overnight, and then cultured $(4 \mathrm{~h})$ in sterile seawater before the experiment.

Table 1: Scale used for evaluation of algal health in bleach and heat trials.

\begin{tabular}{lll}
\hline Rating & $\begin{array}{l}\text { Descriptions for } \\
\text { bleach-treatment }\end{array}$ & $\begin{array}{l}\text { Descriptions for heat- } \\
\text { treatment }\end{array}$ \\
\hline 1 & $\begin{array}{l}\text { No change } \\
\text { Slight discoloration in } \\
\text { algal tissue } \\
\text { White (dead) patches } \\
\text { of algal tissue } \\
>50 \% \text { of the blade was } \\
\text { white }\end{array}$ & $\begin{array}{l}\text { No change } \\
\text { Slight discoloration in algal } \\
\text { tissue } \\
<50 \% \text { of blade }=\text { green }\end{array}$ \\
4 & $\begin{array}{l}\text { Most of blade was } \\
\text { white }\end{array}$ & $\begin{array}{l}>50 \% \text { of blade }=\text { green } \\
\text { Blade was completely green, } \\
\text { but holdfast was redder } \\
\text { Alga }=\text { completely green }\end{array}$ \\
\hline
\end{tabular}


Blades were assigned as controls $(n=3)$ or treated with bleach in seawater at either 50 or 100 ppm ( $n=3$ blades/ ppm level) or treated ( $\mathrm{n}=3$ blades) with sodium hypochlorite from a laboratory grade solution (Carolina Biological Supply Company, Burlington, NC, USA) to make 50 ppm free chlorine. Volumes used in experiments were 31 sterile seawater (controls) or 31 of the specified concentration of free chlorine in sterile seawater produced from the specified hypochlorite source. Controls and treatments were interspersed randomly in each of two chambers. Blades were scored every $15 \mathrm{~min}$ for $2 \mathrm{~h}$ on a five-point scale (Table 1) to record effects of treatment. After $2 \mathrm{~h}$, blades were removed, and rinsed with sterile seawater for $5 \mathrm{~s}$ $(3 \times)$, and observed in culture for 5 days.

\section{Effect of bleach on cystocarpic blades and tetrasporophytic-phase crusts}

Cystocarpic blades of Grateloupia turuturu (1 Oct 2018) and Mastocarpus stellatus (Stackhouse) Guiry (7 Aug 2018), were cleaned with $0.5 \%$ betadine/seawater solution (povidone-iodine 10\%, Rite Aid, Camp Hill, PA, USA) for 2 min and cultured in enriched seawater for 2 days before the experiment. Blades were exposed individually in 31 seawater at either 0,50 , or $100 \mathrm{ppm}$ free chlorine $(\mathrm{n}=3$ blades/species/ppm level). Each set of replicates $(n=3)$ for each chlorine concentration was interspersed between three chambers. Blades were examined every $15 \mathrm{~min}$ for $2 \mathrm{~h}$ for color change. After $2 \mathrm{~h}$, blades were removed, and rinsed with sterile seawater for $5 \mathrm{~s}(3 \times)$. Blades were cultured and observed for 5 days.

Carpospores released from cleaned wild blades of Grateloupia turuturu (see above) were cultured in enriched seawater in Petri dishes for 26 days, and they formed crusts. Replicate dishes with crusts were treated with commercial bleach in $5 \mathrm{ml}$ of seawater at $0(\mathrm{n}=2)$ or $50(n=2)$ ppm free chlorine or maintained in seawater as controls. After $2 \mathrm{~h}$, crusts were rinsed with sterile seawater for $5 \mathrm{~s}(3 \times)$ and cultured in seawater for several weeks of observation. In total, $n=300$ crusts/dish were counted on the day following bleach exposure from 5 to 7 fields of view in each treatment/Petri dish, and each crust was determined to be either alive or dead. Crusts in Petri dishes were followed with regular media changes for 2 months to observe development from surviving and control crusts.

\section{Mastocarpus stellatus bleach experiment}

Experiments were carried out over 3 days to test effects of different concentrations of free chlorine; each individual experimental treatment was replicated between two different culture chambers (see Standard Culture Conditions). For each trial, approximately $3 \mathrm{~g}$ of Mastocarpus stellatus were put into 31 of seawater that contained varying concentrations of free chlorine made up with bleach for $2 \mathrm{~h}$. The concentrations of free chlorine in each treatment were measured at the beginning and end of each trial, in duplicate, through iodometric titrations: day 1 (0, 50, 75, 100, and $125 \mathrm{ppm})$, day 2 (0, 50, 125, 150, $200 \mathrm{ppm})$, and day $3(0,50,200,500,1000 \mathrm{ppm})$. The health of the algae was scored every $15 \mathrm{~min}$ (Table 1). After treatment, each alga was rinsed with sterile seawater, and cultured for observations over the next month. A permutational, nonparametric Wilcoxon-Mann-Whitney test was performed by comparing whether tissue was dead or alive from each individual at 120 min using the package "coins" in R 3.5.1.

\section{Palmaria palmata bleach experiment}

Blades of Palmaria palmata (Linnaeus) F. Weber \& D. Mohr that were approximately the same size were collected on 25 Oct 2018, cleaned with betadine, and cultured in enriched seawater for 2 days before the experiment. Blades were assigned as controls $(n=3)$ or exposed to either 25 or 50 ppm free chlorine in seawater ( $\mathrm{n}=3$ blades/ ppm level). Volumes used in experiments were 31 sterile seawater (controls) or 31 of the specified concentration of free chlorine in sterile seawater produced from bleach. Controls and treatments were interspersed systematically in three chambers. Blades were monitored every $15 \mathrm{~min}$ for $2 \mathrm{~h}$ for color change, rinsed $3 \times(5 \mathrm{~s}$ each $)$ at the end of the experiment and cultured for 5 days.

\section{Heat as an alternative to bleach-treatment}

Wild-collected, large blades and approximately $2 \mathrm{~cm}$-long blades of 1-month old Grateloupia turuturu produced from bleach-treated cystocarps were exposed to elevated temperatures individually in glass beakers $(n=6)$ containing $200 \mathrm{ml}$ seawater at $60^{\circ} \mathrm{C}$ for $2 \mathrm{~h}(\mathrm{n}=3 /$ blade type) or at $75^{\circ} \mathrm{C}$ for $1 \mathrm{~h}$ ( $\mathrm{n}=3 /$ blade type). Additionally, blades of Mastocarpus were also exposed to $60^{\circ} \mathrm{C}$ for $2 \mathrm{~h}(\mathrm{n}=3)$ or $75^{\circ} \mathrm{C}$ for $1 \mathrm{~h}(\mathrm{n}=3)$. Blade health was scored at 15-min intervals using a six-point scale (Table 1). Analysis was carried out on Grateloupia blades by creating and comparing logistic regressions for each series using R 3.5.1 function "glm". Potential recovery was followed for 1 week under standard culture conditions. Media were exchanged after 3 days. 


\section{Results}

\section{Field surveys and verification of Grateloupia turuturu}

Grateloupia turuturu was identified by anatomical and morphological features, and a partial (633 bp) sequence of the rbcL gene (GenBank accession no. MH732764). Herbarium specimens were deposited into the University of Maine Herbarium (Maine-A-002042; Maine-A-002043) and into the Hodgdon Herbarium, University of New Hampshire (NHA-624168). Blades were found within the artificial "subtidal" channel formed from the outfall discharge of seawater from the Darling Marine Center's older seawater labs beginning 22 Sept 2017. Despite monthly removals, new blades appeared in this location even after the outflow was diverted to expose the channel to dry, hot conditions for over a month in July 2018. The only time when blades did not reappear after removal was during the winter when temperatures were $<0^{\circ} \mathrm{C}$. Broader surveys of the Damariscotta Estuary in August - October 2018 revealed a high density of blades at the head of the estuary (Figure 2) compared to the few found seaward in the estuary (e.g. the DMC shore). Blades were attached to a variety of substrates including oyster shells, rocks, ropes (Figure 2), and wood. Both cystocarpic (Figures 3 and 4) and tetrasporic blades (Figure 5) were collected over seven locations, and many morphologies were observed. Tetrasporophytes had the thin, elongated blades, marginal proliferations, and anatomical features described elsewhere (e.g. Gavio and Fredericq 2002). Cystocarpic blades
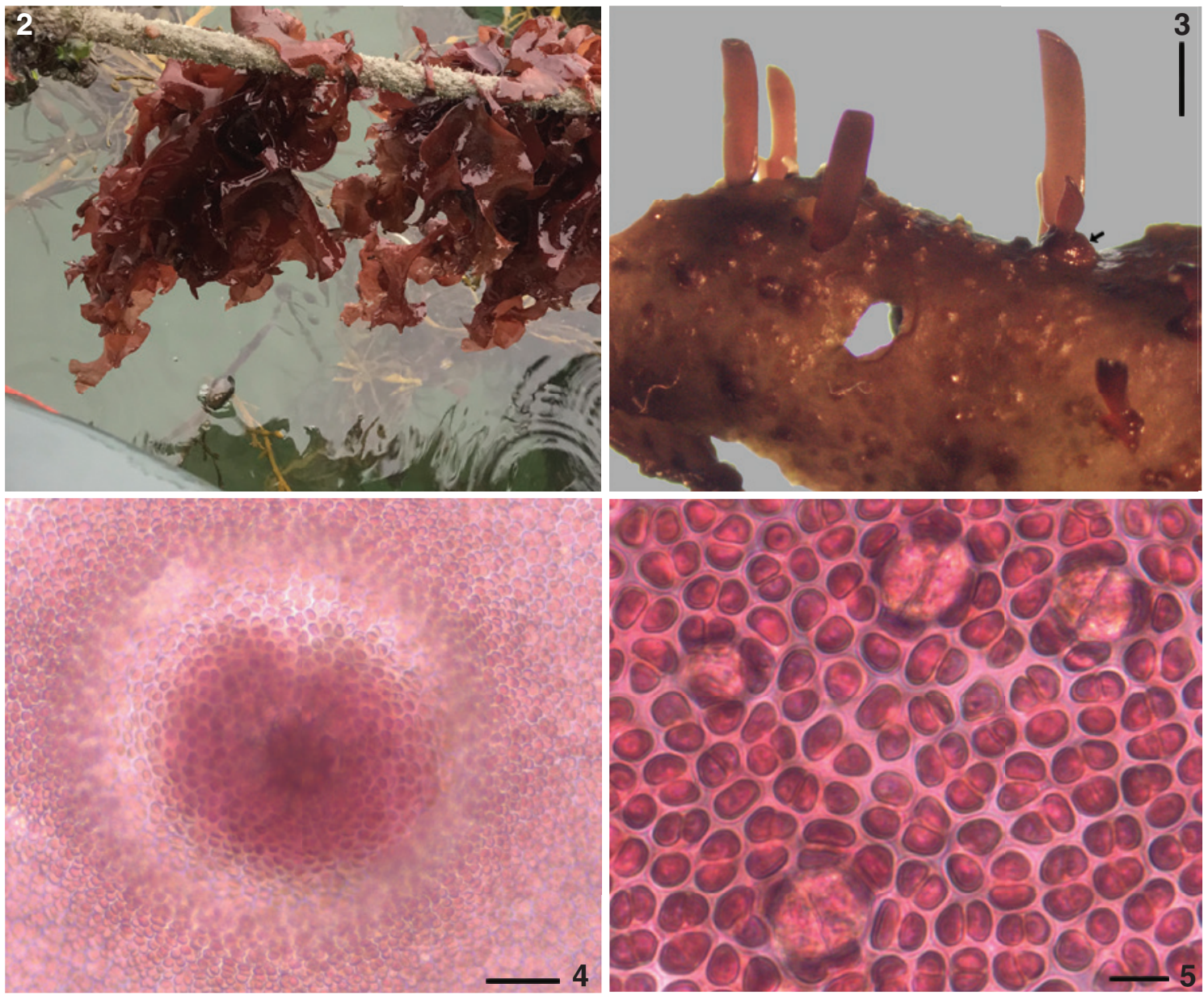

Figures 2-5: Field collections of Grateloupia turuturu in Maine.

(2) Grateloupia turuturu growing on an oyster raft line in the Damariscotta Estuary in October 2018 (photo: Jaclyn Robidoux). (3) Surface proliferations growing from expanded cystocarps (arrow) on wild material collected in October 2018. (4) One of many cystocarps on a wild blade in a composite image. The ostiole was slightly protuberant above the mass of mature carpospores, which were surrounded by mucilage and filaments to create a "halo" effect in surface view. (5) A wild blade with mature tetrasporangia. Scale bars: (Figure 3)=1 mm, (Figure 4) $=33 \mu \mathrm{m}$, (Figure 5) $=10 \mu \mathrm{m}$. 
tended to be wider, also possessed marginal proliferations, and, rarely, had surface proliferations at the base of the blade (Figure 3). Only 2 of about 100 blades examined had such surface proliferations.

\section{Evaluating measurement of free chlorine in seawater for bleach experiments}

In both deionized water and in a 10\% seawater solution in deionized water, the calculated addition of bleach to make $25 \mathrm{ppm}\left(25 \mathrm{mg} \mathrm{l}^{-1}\right)$ free chlorine was determined accurately with the test trips as $25 \mathrm{ppm}$ by reading color changes against HACH's strip color chart (Table 2). However, as the concentration of seawater increased, so did the apparent amount of free chlorine in the solution, although each solution was prepared to have $25 \mathrm{ppm}$ free chlorine. Test strips read $25 \mathrm{ppm}$ free chlorine as $100 \mathrm{ppm}$ in $25 \%$ seawater, and as 200 ppm in 50, 75, or $100 \%$ seawater; simultaneous iodometric determinations of free chlorine were close to 25 ppm (Table 2).

A series of test solutions containing a calculated $50 \mathrm{ppm}$ free chlorine from bleach was used to evaluate $\mathrm{Br}^{-}$interference of free chlorine measurement with $\mathrm{HACH}$ test strips. Bromide alone did not appear to cause interference, because the change in test strip color indicated the

Table 2: Comparison of free chlorine concentration measured by iodometric titration or test strips from solutions calculated to be $25 \mathrm{ppm}$ free chlorine.

\begin{tabular}{lrrr}
\hline $\begin{array}{l}\text { Seawater } \\
\text { concentration (\%) }\end{array}$ & $\begin{array}{r}\text { lodometric reading (ppm) } \\
\text { Mean }(\mathbf{E S D}, \mathbf{n = 2})\end{array}$ & $\begin{array}{r}\text { Strip reading } \\
(\mathbf{p p m})\end{array}$ & $\mathbf{p H}$ \\
\hline 0 & $27.2(6.4)$ & 25 & 8.7 \\
10 & $33.8(5.3)$ & 25 & 8.8 \\
25 & $41.7(5.4)$ & 100 & 8.5 \\
50 & $34.0(5.4)$ & 200 & 8.5 \\
75 & $31.4(0)$ & 200 & 8.3 \\
100 & $31.6(0)$ & 200 & 8.2 \\
\hline
\end{tabular}

Table 3: Interference effects of chloride and bromide on test strip determination of solutions calculated to provide $50 \mathrm{ppm}$ free chlorine.

\begin{tabular}{lr}
\hline Solution & $\begin{array}{r}\text { Apparent free chlorine (ppm) } \\
\text { as read from color chart }\end{array}$ \\
\hline Deionized water & 50 \\
$0.6 \mathrm{mM} \mathrm{NaBr}$ & 50 \\
$0.45 \mathrm{M} \mathrm{NaCl}$ & 200 \\
$0.6 \mathrm{mM} \mathrm{NaBr}+0.45 \mathrm{M} \mathrm{NaCl}$ & $200-400$ \\
Sterile seawater & 200 \\
\hline
\end{tabular}

expected $50 \mathrm{ppm}$ free chlorine in either deionized water or a $0.6 \mathrm{~mm} \mathrm{NaBr}$ solution (Table 3; Supplementary Figure S1). However, at higher chloride levels, strip color change led to inaccurate free chlorine determination, because $0.45 \mathrm{M} \mathrm{NaCl}+0.6 \mathrm{~mm} \mathrm{NaBr}$ caused test strips to read higher ( $>200 \mathrm{ppm}$ ) than either the $0.45 \mathrm{M} \mathrm{NaCl}$ solution or seawater, which were estimated as $200 \mathrm{ppm}$ against the $\mathrm{HACH}$ strip color guide. LaMotte test strips in a limited trial (50 ppm free chlorine in deionized water versus seawater) had similar inaccuracies.

\section{Effects of free chlorine on Grateloupia turuturu and native red macroalgae}

\section{$50 \mathrm{ppm}$ free chlorine}

Three tested species (Grateloupia turuturu, Palmaria palmata, Mastocarpus stellatus) responded differently to $50 \mathrm{ppm}$ free chlorine for $2 \mathrm{~h}$. Blades of Palmaria (Figure 6) turned pale after $<30$ min exposure, and only small portions of the proximal base $(2-3 \mathrm{~mm})$ of the holdfast remained red after $2 \mathrm{~h}$ (Figure 7). Blades of wild Grateloupia lost pigment too, but not to the same degree, especially because cystocarps remained red (Figures 8 and 9). No difference was found in wild blades whether the free chlorine was supplied by chemical sodium hypochlorite or commercial bleach, but blades brought into culture for $\geq 1$ month before treatment were resilient to $50 \mathrm{ppm}$ bleach, retaining deep red color across the blade. Carpospores from wild plants germinated to form crusts (Figures 12 and 13) that died when treated with $50 \mathrm{ppm}$ free chlorine except where the crusts were covered by diatoms (mean survival of control crusts: $92 \pm 2.4 \%$ (SD); mean survival of bleachtreated crusts: $2.4 \pm 2.4 \%$ (SD); Figure 12). While much of the surrounding cortical and medullary tissue turned pale, a sub-region of the cystocarps of $50 \mathrm{ppm}$-treated blades was often still red (cf., Figures 14, 16). Additionally, some cystocarps from bleach-treated wild blades released carpospores within 7 days of treatment that were viable, although some cystocarps expanded in situ as described below (100 ppm). Fronds of Mastocarpus were nearly unchanged post-treatment (Figures 10 and 11). Grateloupia and Mastocarpus grew during recovery.

\section{0-1000 ppm free chlorine}

Cystocarps and holdfasts of Grateloupia turuturu blades exposed to $100 \mathrm{ppm}$ free chlorine for $2 \mathrm{~h}$ (wild blades) or up to $4 \mathrm{~h}$ (cultured blades) survived, but vegetative 


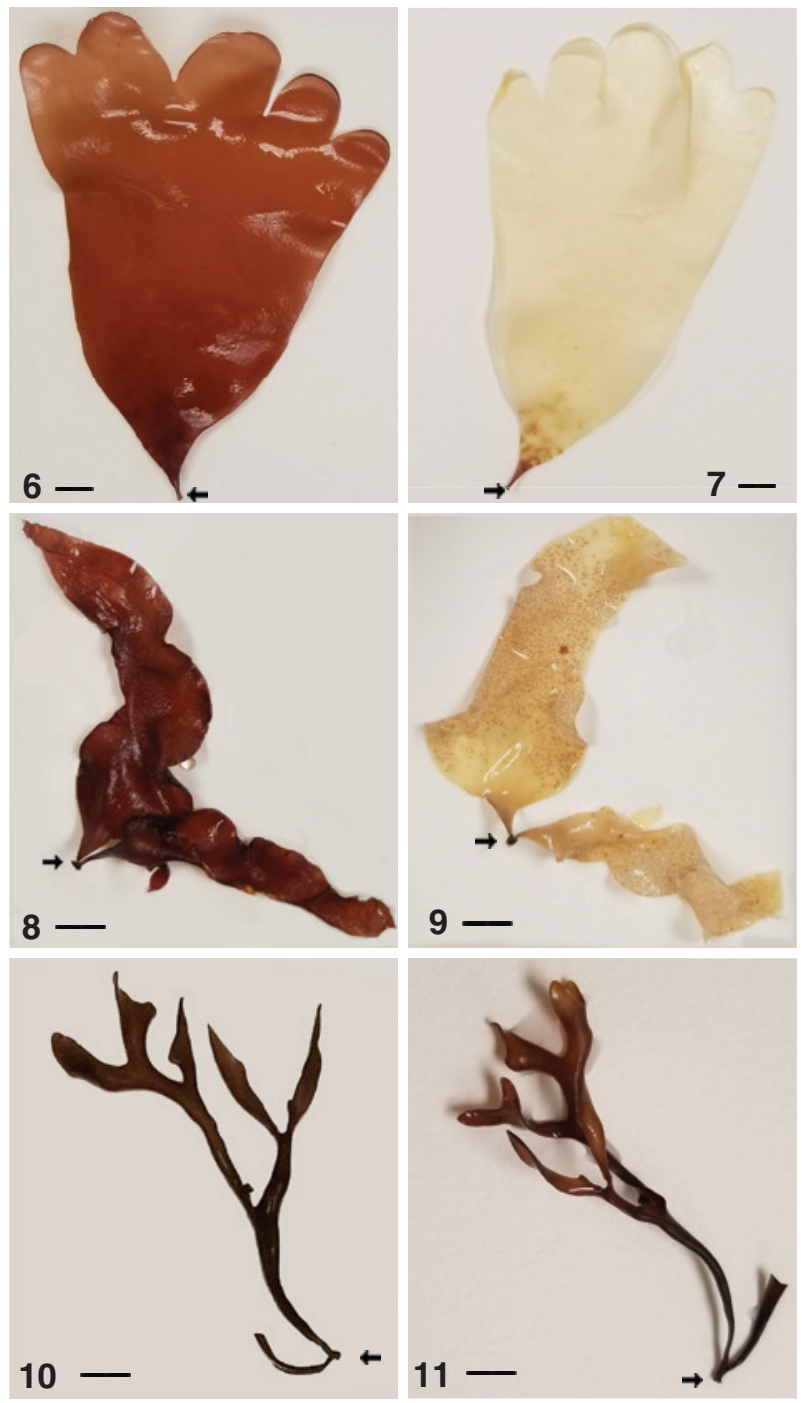

Figures 6-11: Bleach treatment of red macroalgae.

Palmaria palmata (Figures 6 and 7), Grateloupia turuturu (Figures 8 and 9), and Mastocarpus stellatus (Figures 10 and 11) before (Figures $6,8,10$ ) and after (Figures 7, 9, 11) exposure to seawater containing $50 \mathrm{ppm}$ free chlorine from bleach for $2 \mathrm{~h}$. Arrows point to the holdfasts. Note mottling in Figure 9, which is due to surviving red cystocarps. Scale bar $=0.5 \mathrm{~cm}$.

areas of the blade turned white by the end of the experiments (Figure 15). New terete axes emerged directly from most cystocarps of bleach-treated, cultured blades after 5 weeks (Figures 17 and 18). Before this, expansion of the cystocarpic area occurred (cf., Figures 16, 18), and this coalescence and/or callus-like growth was particularly evident in cross section (Figure 18). The axes flattened out after 1 month (Figure 19) and matured to fertile tetrasporophytes (Figures 20 and 21).

Although Mastocarpus stellatus was resistant to $50 \mathrm{ppm}$ free chlorine, increasing the concentration of
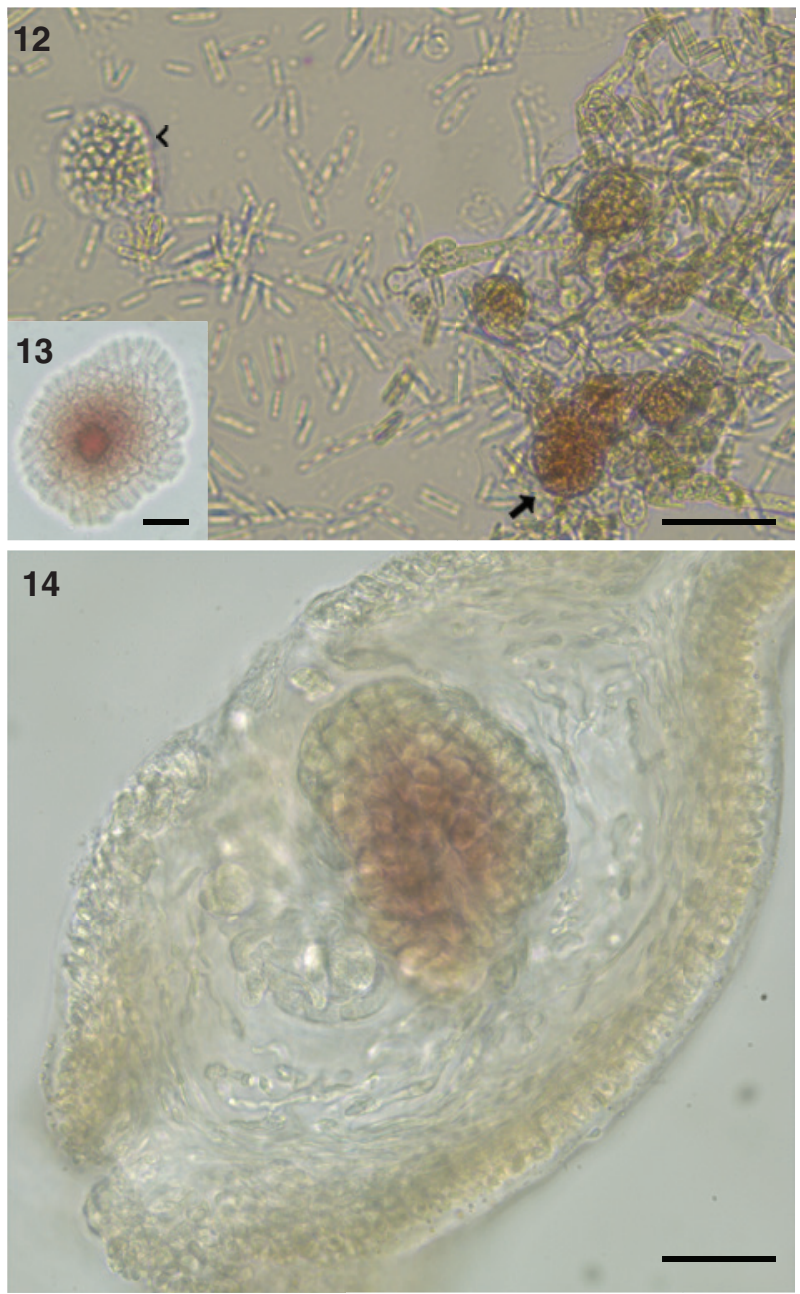

Figures 12-14: Bleach treatment of carpospores.

(12) Grateloupia turuturu crusts after bleach-treatment, showing a dead crust (arrowhead) and surviving crusts covered by diatoms (arrow). (13) An example of a crust with a terete axis (red center) beginning to grow vertically. (14) Cross-section of a $50 \mathrm{ppm}$ bleachtreated cystocarp (wild blade) immediately after the $2 \mathrm{~h}$ exposure showing killed areas in the cortex and medulla of the blade but some surviving areas of cystocarp (cf., Figure 16). Scale bars: $($ Figure 12) $=50 \mu \mathrm{m}$, (Figure 13) $=5 \mu \mathrm{m}$, (Figure 14) $=37.5 \mu \mathrm{m}$.

free chlorine did have negative effects (Wilcoxon-MannWhitney Test, $\left.\mathrm{Z}=-4.4467, \mathrm{p}=8.722 \times 10^{-6}\right)$. However, holdfasts remained dark red, and cystocarps, when present, also remained red in experimental treatments at $1000 \mathrm{ppm}$ free chlorine (Figures 22-24). Vegetative tissue died after $2 \mathrm{~h}$ in treatments $>125 \mathrm{ppm}$, and a rapid effect (i.e. whitened tissue after $15 \mathrm{~min}$ ) occurred in treatments $\geq 500 \mathrm{ppm}$ (Table 4). Iodometric determinations found no significant degradation of free chlorine during the experiment, and calculated additions of bleach to produce free chlorine at different levels were found to be accurate by iodometric determinations (Table 2). 

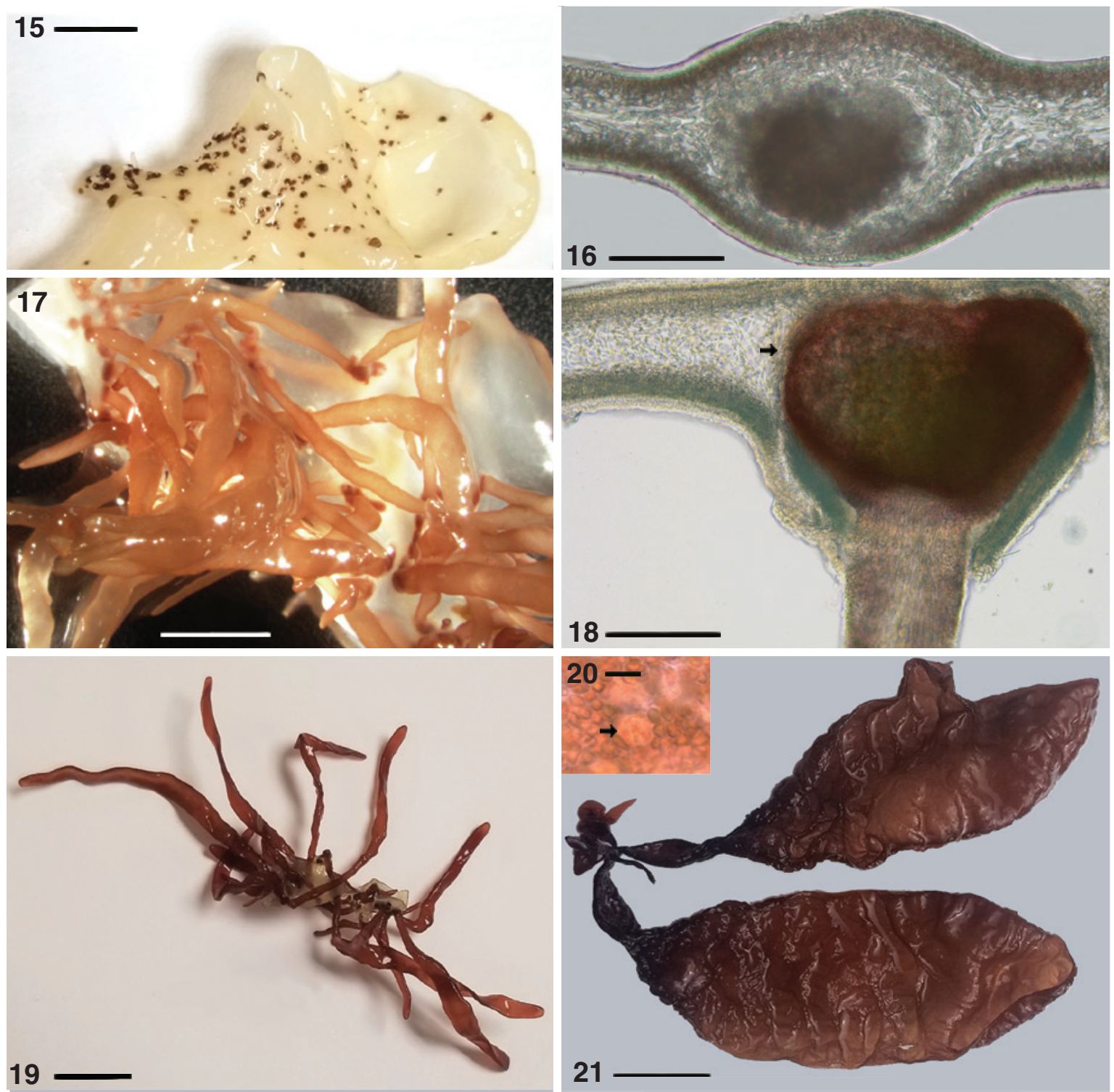

Figures 15-21: Survival of bleach-treated cystocarps.

(15) Grateloupia turuturu (cultured) that was bleach-treated for $4 \mathrm{~h}$ at $100 \mathrm{ppm}$ free chlorine. (16) Cross-section of a cystocarp containing many carpospores in an untreated wild blade. (17) Terete axes grown from cystocarps (1 axis/1 cystocarp) embedded in dead vegetative tissue. (18) Cross-section of a new axis (see Figure 17) that grew from expanded, callus-like growth of a cystocarp during culture of a blade after bleach-treatment; note the compact area of closely appressed cells (pericarp, arrow) that border the enlarging cystocarp. (19) Axes flattened out while still attached to dead blade tissue. (20) Tetrasporangia formed (arrow) as blades matured (Figure 21). Scale bars: (Figures $15,19,21)=2 \mathrm{~cm}$, (Figures 16, 18) $=200 \mu \mathrm{m},($ Figure 17) $=2 \mathrm{~mm},($ Figure 20) $=40 \mu \mathrm{m}$.

\section{Heat as an alternative to bleach treatment}

In $60^{\circ} \mathrm{C}$ seawater, large wild blades of Grateloupia turuturu turned green due to faster loss of pigment than from the small blades that were grown up in culture, and the holdfast region remained red longer than the rest of the blade in both types of test material (Figure 25). Both wild and cultured blades turned green nearly instantaneously in the $75^{\circ} \mathrm{C}$ treatment. A small red $\left(75^{\circ} \mathrm{C}\right)$ or $\tan \left(60^{\circ} \mathrm{C}\right)$ area remained at the base of the small blades, and this corresponded to the callus-like cystocarp region from which each terete axis formed (see Figure 18). After 7 days in standard culture, all blades from both heat experiments had died and were completely white (Supplementary Figure S2). Blades of Mastocarpus stellatus became mostly white, but some pigmented regions remained even after a month; they were considered dead because there was no new growth. 

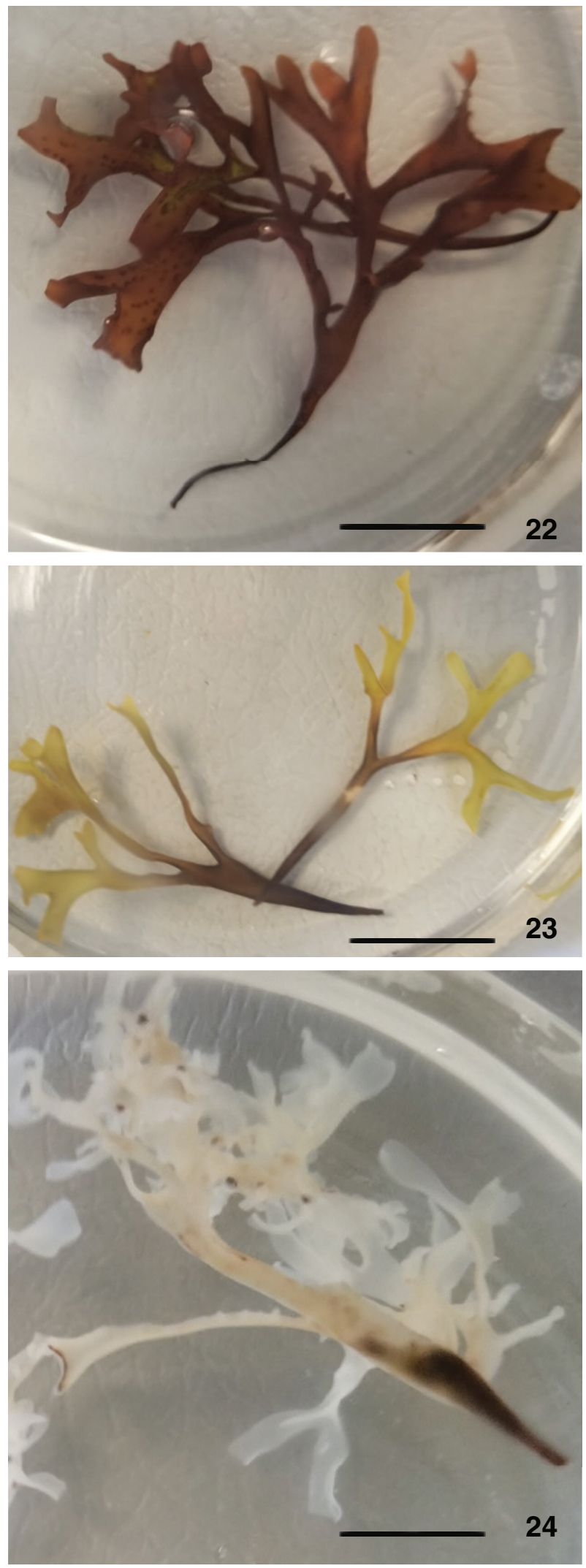

Figures 22-24: Mastocarpus stellatus after bleach treatment. Mastocarpus stellatus 7 days after bleach-treatment at $0 \mathrm{ppm}$ (Figure 22), 50 ppm (Figure 23), and 1000 ppm free chlorine (Figure 24). Scale bar $=1 \mathrm{~cm}$.
Table 4: Categorical scoring (Table 1) in changes of health over time during bleach-treatment of Mastocarpus Mean ( $\pm \mathrm{SD}$; all $S \mathrm{SD}=0$ ).

\begin{tabular}{lrrr}
\hline Free chlorine treatment (ppm) & $\mathbf{1 5} \mathbf{~ m i n}$ & $\mathbf{1 ~ h}$ & $\mathbf{2 ~ h}$ \\
\hline $0(\mathrm{n}=6)$ & 1 & 1 & 1 \\
$50(\mathrm{n}=6)$ & 1 & 1 & 2 \\
$75(\mathrm{n}=2)$ & 1 & 2 & 2 \\
$100(\mathrm{n}=2)$ & 1 & 2 & 2 \\
$125(\mathrm{n}=4)$ & 1 & 2 & 2 \\
$150(\mathrm{n}=2)$ & 1 & 2 & 3 \\
$200(\mathrm{n}=4)$ & 1 & 2.5 & 4 \\
$500(\mathrm{n}=2)$ & 2 & 3 & 4 \\
$1000(\mathrm{n}=2)$ & 2 & 3.5 & 5 \\
\hline
\end{tabular}

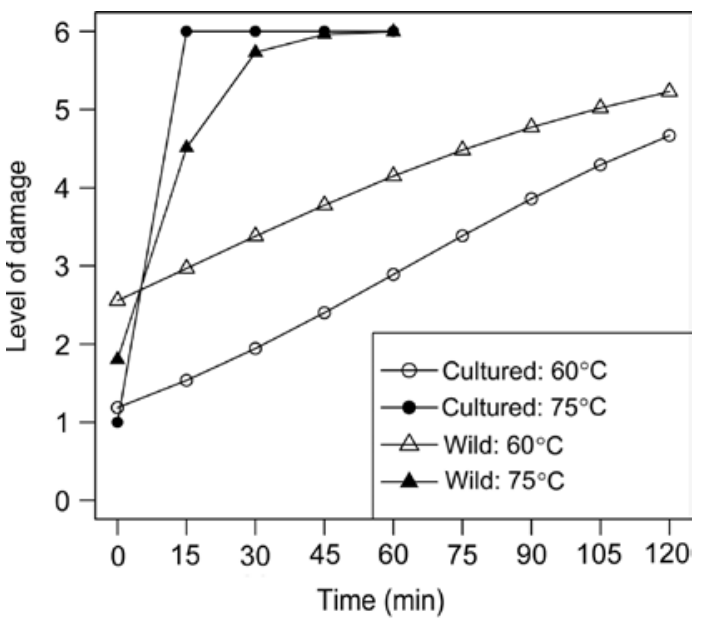

Figure 25: Grateloupia turuturu damage (see Table 1 for scoring parameters) during each heat experiment $\left(60^{\circ} \mathrm{C}, 75^{\circ} \mathrm{C}\right)$ of freshly collected ( 9 July 2018) wild blades and cultured blades.

\section{Discussion}

The vector for establishment of Grateloupia turuturu in the Damariscotta Estuary is unknown. Globally, G. turuturu's introduction is associated with shellfish aquaculture (Verlaque et al. 2005, Bolton et al. 2016), and there are many shellfish aquaculture lease sites along the Damariscotta estuary, as well as historical experiments with imported oysters (Packie et al. 1976). However, there are numerous other possible vectors including hull-fouling of boats that move between the Damariscotta and areas south of Maine where G. turuturu is common. We have demonstrated that biosecurity procedures used under DMR mandate in shellfish aquaculture or adopted proactively by others (additional aquaculture facilities, research labs) will not kill G. turuturu blades or diatom-covered crusts. The large amount of $G$. turuturu found in multiple locations at the head of the estuary in fall 2018 suggests that primary 
establishment occurred in this area of the estuary with secondary establishment on mid-estuarine buoys and the DMC shore.

\section{Why are Grateloupia and some other red algae so resistant to bleach-treatment?}

The resistance of Grateloupia turuturu to biosecurity protocols led us to investigate whether other macroalgae were also resistant. Mastocarpus stellatus is one of the most stress-tolerant species of red algae in the North Atlantic intertidal zone (e.g. Dudgeon et al. 1995), so special attention was paid to using it to determine the upper limit of macroalgal tolerance to bleach. Because Mastocarpus was able to survive a $1000 \mathrm{ppm}$ chlorination treatment, the ranked order of resistance among tested red algae was Mastocarpus $>$ Grateloupia $>$ Porphyra umbilicalis (data not shown) $>$ Palmaria palmata.

Resistance to bleach likely results from a combination of biochemical and anatomical features, some of which may have evolved as general defenses against physical stress, especially in the red algae (Rhodophyta) that have the oldest eukaryotic multicellular fossils known (Gibson et al. 2017) and include a deeply diverged clade (Cyanidiophyceae) of unicellular freshwater species that live at $60^{\circ} \mathrm{C}$ (Yoon et al. 2016). Bleach creates reactive oxygen stress (ROS), and many red macroalgae have ROS scavenging enzymes (Collén and Davison 1999, Collén et al. 2013, Brawley et al. 2017), including haloperoxidases that consume ROS-generated $\mathrm{H}_{2} \mathrm{O}_{2}$ in halogenation of organic substrates (Butler and Walker 1993). Indeed, the most sensitive species in our tests, Palmaria palmata, has less superoxide dismutase (SOD) and peroxidase (POD) than Grateloupia turuturu (Liu and Pang 2010). Furthermore, the cell walls and interior mucilage of G. turuturu are composed of sulfated polysaccharides including carrageenan (Denis et al. 2009, Rodrigues et al.2015) that present bleach-reactive surfaces and may retard penetration of damage, especially to reproductive structures such as the embedded, resistant cystocarps documented here, given the large amount of mucilage around carpospores.

Prominent cystocarps are produced within the Halymeniales, where they are embedded in the inner cortex and medulla of the blade (Chiang 1970, Gargiulo et al. 2013). The cystocarp is bordered by a protective layer called the pericarp that encases the carposporophyte and is composed of a compressed, encircling meshwork of cells belonging to the female gametophyte that can become joined by pit plugs (e.g. lateral branching of ampullary filaments, medullary filaments, inner cortical cells, see Chiang 1970, Hommersand and Fredericq 1990, Verlaque et al. 2005). Remnants of the pericarp and mucilage within the cystocarps were evident around cystocarps that survived bleach-treatment in our experiments. There is convergent morphology across cystocarps in a number of red algal orders, although anatomical development varies (Hommersand and Fredericq 1990), so it is perhaps not surprising that we observed red cystocarps in otherwise dead, white blades not only in Grateloupia turuturu thalli treated with $100 \mathrm{ppm}$ free chlorine but also in the more protuberant cystocarps of Mastocarpus stellatus (Gigartinales), which produce carpospores that on the Maine shore typically develop apomictically back into fronds rather than tetrasporophytic crusts (Dudgeon et al. 1995). Notably, mucilage that is likely to resist bleach is also abundant around developing carpospores within the cystocarp (Boney 1981, Baweja and Sahoo 2002). We did not follow the fate of apparently bleach-resistant $M$. stellatus cystocarps.

Why single fronds developed from single cystocarps in 100 ppm free chlorine-treated blades of Grateloupia turuturu is unknown. This was surprising, because each cystocarp contains hundreds of carpospores. A possible explanation is that stranding of cystocarps, possibly partially damaged, within the otherwise dead blade triggered either: (1) coalescence, which can occur between spores and lead to more stress-resistant erect thalli in some red algae (e.g. Medina et al. 2015) and/or (2) callus formation, which is known specifically from $G$. turuturu to be able to produce new fronds (Huang and Fujita 1997, Baweja and Sahoo 2009, also see Shao et al. 2004 for crust formation before production of erect thalli). The axes that grew from bleach-treated cystocarpic blades developed into mature tetrasporophytes after the rest of the blade degenerated. We subsequently found a few wild blades in the Damariscotta with surface proliferations emerging from expanded cystocarps, visually identical to our experimental results. Villalard-Bohnsack and Harlin (1997) mentioned rare surface proliferations: " 1 in more than 500 surveyed". It does not appear that these surface proliferations have been recognized as originating from expanded cystocarps. Our finding of some blades with proliferations erupting from cystocarps at the older, thicker bases of a few wild blades in the Damariscotta suggests that a stress such as very cold to freezing temperatures in winter can trigger the same response as bleach. The greater susceptibility suffered by G. turuturu in our collection from the DMC shore in summer (9 July 2018) compared to wild blades earlier brought into laboratory culture for $\geq 1$ month 
before exposure to bleach is likely due to the blades being stressed by lower summer nutrient levels prior to collection and immediate treatment.

Growth of new blades from cystocarps of otherwise bleach-killed vegetative tissue is particularly significant to the issue of invasion vectors. The dead tissue eroded over time in our experiments to release young plants into our culture vessels, and these became mature tetrasporophytes. From any number of relevant coastal facilities using bleach for biosecurity, similar results might increase establishment potential of Grateloupia turuturu as a non-indigenous species. Therefore, this represents discovery of a form of vegetative propagation and fragmentation that could increase the establishment potential of G. turuturu beyond that known to Nyberg and Wallentinus (2005) in their scoring of risk potential of invasive macroalgae. These results suggest that evolution of the cystocarp in red algae may have been a response to physical stresses in terms of the degree to which anatomical features protect this structure more than vegetative areas of the blade.

Survival of crusts (juvenile tetrasporophytes) in our experiments when they were covered by pennate diatoms and diatom mucilage is a significant finding. Diatom coverage of crusts should be common in natural and anthropogenic settings. For example, the microscopic crust's survival would not be recognizable in any biosecurity facility or on shells or gear transported from an aquaculture site to another location.

\section{Chlorination and its measurement for effective biosecurity}

Chlorination remains a widely used disinfection method despite it not effectively meeting the goals of all users at an economic and environmentally safe level. For example, Pignata et al. (2012) reported that chlorination has increased the residual toxicity of wastewater above United States Environmental Protection Agency (EPA) standards and failed to consistently reduce the concentration of Escherichia coli below European standards in some wastewater. EPA regulations also set a maximum allowable chlorine residual in wastewater, and neutralization of chlorine to obtain acceptable residual levels before discharge may be required, which adds to operation costs if bleach is used for biosecurity. Many byproducts, some of which are toxic, can be formed through the reactions of bleach and organic material, including absorbable organic halides (AOX), trihalomethanes (THM), haloacetic acids (HAAs), and other organohalides (Emmanuel et al. 2004, Hua and Reckhow 2007). Significantly, Grateloupia turuturu responded inconsistently to chlorination in our experiments with blades growing in culture under high nutrient conditions being particularly resilient. Furthermore, organisms such as bacteria can acquire resistance to biocides such as bleach through mutations or plasmid transfer (Russell 1999).

Rare survival to $50 \mathrm{ppm}$ free chlorine was found by Williams and Schoeder (2004) in their studies of invasive Caulerpa taxifolia, and they recommended $125 \mathrm{ppm}$ free chlorine based on their experiments, but they also found heat $\left(75^{\circ} \mathrm{C}\right)$ to be effective. Several Chaetomorpha species also are reported to be highly resistant to chlorination (Odom and Walters 2015). Also pointing to macroalgal resistance to bleach-based protocols, bleach as a $1 \%$ bleach $/ 40 \%$ ethanol solution is recommended by Kientz et al. (2011) to remove unwanted microflora from macroalgae. This evidence of resistance suggests that chlorine is unreliable as an effective biocontrol agent against the spread of invasive macroalgal species.

Our results demonstrated that the wide application of high chlorine test strips for monitoring free chlorine in biosecurity procedures in seawater is inappropriate. Further, if, rather than calculating free chlorine, bleach was added to a tank or pit until a test strip registered $50 \mathrm{ppm}$, less free chlorine would be present to kill organisms than expected, because the test strips read high compared to iodometric determination of free chlorine, which matched our calculated additions of bleach to achieve different levels of free chlorine. The apparent amount of free chlorine measured using high range free chlorine test strips (HACH or LaMotte) was consistently higher than expected when measurements were taking place in seawater, likely due to reaction with halides found in seawater. Hach Corp. was unaware that these test strips, which are intended for freshwater municipal facilities, swimming pool managers, and similar users, were being used in marine applications (Hach Corp. Technical Staff, pers com to KCF, SHB, 18/6/18), and immediately posted a note on the product information (https://www.hach.com/free-chlorine-test-strips-0-600mg-1-100-tests/product-details?id=7640211621, accessed 16/2/2019) to indicate that they should not be used for marine or brackish applications. Bromide ions react rapidly with the hypochlorite ion to form hypobromous acid, another widely used and more potent disinfectant (Emmanuel et al. 2004). At high bleach concentrations in natural situations where organic bromoforms may be present in addition to the typical $65 \mathrm{ppm}$ bromine in 
seawater, further interference in measurement of free chlorine can be expected (Bousher et al. 1986). To the best of the authors' knowledge, no reliable, quick field method exists to measure free chlorine in seawater, and caution should be exercised in applying biosecurity protocols based on chlorination to marine conditions (also see Steininger and Pareja 1996 [Oxidation-reduction potential] and Harp 2002).

\section{What is the most effective marine biosecurity strategy?}

Many sterilization and biocontrol procedures (e.g. chlorination, filtration, heat-treatment, ozonation, UV irradiation, Timmons et al. 2002) are used in aquacultural settings. Chlorination (50-100 ppm) was not effective against Grateloupia turuturu, and our results, as well as previous studies (e.g. Williams and Schoeder 2004), demonstrate that other strategies are needed to prevent macroalgal non-indigenous species from becoming established. All the macroalgae we tested died completely within a week of short treatment in seawater at $75^{\circ} \mathrm{C}$; thus, we recommend heat as an additional option for facilities needing biosecurity. If heat were used after a 50-125 ppm free chlorine treatment, little bleach would remain to require neutralization with sodium thiosulfate (Shams El Din et al. 2000). Heat was also recommended in New Zealand to sterilize aquaculture equipment to stop the spread of the invasive kelp Undaria pinnatifida (Forrest and Blakemore 2006).

Based on our results, we recommend heat and/or prolonged drying under the sun as additional cost-effective, environmentally safe, and viable steps to comprehensive biosecurity compared to bleach-treatment alone.

Acknowledgments: We are grateful to Maura Niemisto, Timothy Miller, and Dr. Heather Leslie (University of Maine); Dana Morse and Jaclyn Robidoux (Maine Sea Grant); and Marcy Nelson and Deidre Gilbert (Maine Dept. of Marine Resources) for making additional collections and/or discussions about biosecurity regulations; Riley Cummings (University of Maine) for herbarium curation and to Technical Staff at the Hach Corporation and Dr. Larry Mayer (University of Maine) for discussion of bleach chemistry. We thank the anonymous reviewers and Editor-in-Chief for their helpful comments. This research was supported in part by Maine Sea Grant contract \#NA140AR4170072 (SHB), a University of Maine Research Reinvestment Fund award (KCF, SHB), and a National Science Foundation award to Maine EPSCoR at the University of Maine.

\section{References}

Andersen, R. 2005. Algal culturing techniques. 1st edition. Elsevier, Amsterdam. pp. 1-596.

Baweja, P. and D. Sahoo. 2002. Structure and reproduction of Grateloupia filicina (Halymeniaceae, Rhodophyta) from Indian Coast. Algae 17: 161-170.

Baweja, P. and D. Sahoo. 2009. Regeneration studies in Grateloupia filicina (J.V. Lamouroux) C. Agardh - an important carrageenophyte and edible seaweed. Algae 24: 163-168.

Bolton, J.J., O. De Clerck, C.M. Francis, F. Siyanga-Tembo and R. J. Anderson. 2016. Two newly discovered Grateloupia (Halymeniaceae, Rhodophyta) species on aquaculture rafts on the west coast of South Africa, including the widely introduced Grateloupia turuturu. Phycologia 55: 659-664.

Boney, A.D. 1981. Mucilage: the ubiquitous algal attribute. Br. Phycol. J. 16: 115-132.

Bousher, A., P. Brimblecombe and D. Midgley. 1986. Rate of hypobromite formation in chlorinated seawater. Wat. Res. 7: 865-870.

Brawley, S.H., N.A. Blouin, E. Ficko-Blean, G.L. Wheeler, M. Loh, H.V. Goodson, J.W. Jenkins, C. Blaby-Haas, K.E. Helliwell, C.X. Chan, T.N. Marriage, D. Bhattacharya, A. Klein, Y. Badis, J. Brodie, Y.Y. Cao, J. Collén, S.M. Dittami, C.M. Gachon, B.R. Green, S.J. Karpowicz, J.W. Kim, U.J. Kudahl, S. Lin, G. Michel, M. Mittag, B.J.S. Olson, J.L. Pangilinan, Y. Peng, H. Qiu, S.Q. Shu, J.T. Singer, A. Smith, B.N. Sprecher, V. Wagner, W. Wang, J. Yan, C. Yarish, S. Zäuner-Riek, Y.Y. Zhuang, Y. Zou, E.A. Lindquist, J. Grimwood, K. Barry, D.S. Rokhsar, J. Schmutz, J.W. Stiller, A.R. Grossman and S.E. Prochnik. 2017. Insights into the red algae and eukaryotic evolution from the genome of Porphyra umbilicalis (Bangiophyceae, Rhodophyta). Proc. Natl. Acad. Sci. USA. 114: E6361-E6370.

Brodie, J., J. Wilbraham, J. Pottas and M.D. Guiry. 2016. A revised check-list of the seaweeds of Britain. J. Mar. Biol. Assoc. United Kingdom 96: 1005-1029.

Butler, A. and J.V. Walker. 1993. Marine haloperoxidases. Chem. Rev. 93: 1937-1944.

Carlton, J.T. and J.B. Geller. 1993. Ecological roulette: the global transport of nonindigenous marine organisms. Science 261: 78-82.

Carlton, J.T., J.W. Chapman, J.B. Geller, J.A. Miller, G.M. Ruiz, D.A. Carlton, M.I. McCuller, N.C. Treneman, B.P. Steves, R.A. Breitenstein, R. Lewis, D. Bilderback, D. Bilderback, T. Haga and L.H. Harris. 2018. Ecological and biological studies of ocean rafting: Japanese tsunami marine debris in North America and the Hawaiian Islands. Aquat. Invasions 13: 1-9.

Chiang, Y.-M. 1970. Morphological studies of red algae of the family Cryptonemiaceae. University of California Press, Berkeley. pp. 1-95.

Collèn, J. and I.R. Davison. 1999. Stress tolerance and reactive oxygen metabolism in the intertidal red seaweeds Mastocarpus stellatus and Chondrus crispus. Plant Cell Environ. 22: $1143-1151$.

Collén, J., B. Porcel, W. Carré, S.G. Ball, C. Chaparro, T. Tonon, T. Barbeyron, G. Michel, B. Noel, K. Valentin, M. Elias, F. Artiguenave, A. Arun, J.-M. Aury, J.F. Barbosa-Neto, J.H. Bothwell, F.-Y. Bouget, L. Brillet, F. Cabello-Hurtado, S. CapellaGutiérrez, B. Charrier, L. Cladière, J.M. Cock, S.M. Coelho, C. Colleoni, M. Czjzek, C. Da Silva, L. Delage, F. Denoeud, P. Deschamps, 
S.M. Dittami, T. Gabaldón, C.M.M. Gachon, A. Groisillier, C. Hervé, K. Jabbari, M. Katinka, B. Kloareg, N. Kowalczyk, K. Labadie, C. Leblanc, P.J. Lopez, D.H. McLachlan, L. Meslet-Cladiere, A. Moustafa, Z. Neh, P.N. Collén, O. Panaud, F. Partensky, J. Poulain, S.A. Rensing, S. Rousvoal, G. Samson, A. Symeonidi, J. Weissenbach, A. Zambounis, P. Wincker and C. Boyen. 2013. Genome structure and metabolic features in the red seaweed Chondrus crispus shed light on evolution of the Archaeplastida. Proc. Natl. Acad. Sci. USA. 110: 5247-5252.

D’Archino, R., W.A. Nelson and G.C. Zuccarello. 2007. Invasive marine red alga introduced to New Zealand waters: first record of Grateloupia turuturu (Halymeniaceae, Rhodophyta). New Zeal. J. Mar. Freshw. Res. 41: 35-42.

Denis, C., M. Morançais, P. Gaudin and J. Fleurence. 2009. Effect of enzymatic digestion on thallus degradation and extraction of hydrosoluble compounds from Grateloupia turuturu. Bot. Mar. 52: 262-267.

Dudgeon, S.R., J.E. Kubler, R.L. Vadas and I.R. Davison. 1995. Physiological responses to environmental variation in intertidal red algae: does thallus morphology matter? Mar. Ecol. Prog. Ser. 117: 193-206.

Emmanuel, E., G. Keck, J.M. Blanchard, P. Vermande and Y. Perrodin. 2004. Toxicological effects of disinfections using sodium hypochlorite on aquatic organisms and its contribution to AOX formation in hospital wastewater. Environ. Int. 30: 891-900.

Forrest, B.M. and K.A. Blakemore. 2006. Evaluation of treatments to reduce the spread of a marine plant pest with aquaculture transfers. Aquaculture 257: 333-345.

Freshwater, D.W. and J. Rueness. 1994. Phylogenetic relationships of some European Gelidium (Gelidiales, Rhodophyta) species, based on $r b c L$ nucleotide sequence analysis. Phycologia 33: 187-194.

Fukuzaki, S. 2006. Mechanisms of actions of sodium hypochlorite in cleaning and disinfection processes. Biocontrol Sci. 11: 147-157.

Gargiulo, G.M., M. Morabito and A. Manghisi. 2013. A re-assessment of reproductive anatomy and postfertilization development in the systematics of Grateloupia (Halymeniales, Rhodophyta). Cryptogam. Algol. 34: 32.

Gavio, B. and S. Fredericq. 2002. Grateloupia turuturu (Halymeniaceae, Rhodophyta) is the correct name of the non-native species in the Atlantic known as Grateloupia doryphora. Eur. J. Phycol. 37: 349-359.

Gibson, T.M., P.M. Shih, V.M. Cumming, W.W. Fischer, P.W. Crockford, M.S.W. Hodgskiss, S. Worndle, R.A. Creaser, R.H. Rainbird, T.M. Skulski and G.P. Halverson. 2017. Precise age of Bangiomorpha pubescens dates the origin of eukaryotic photosynthesis. Geology 46: 135-138.

Hanyuda, T., G.I. Hansen and H. Kawai. 2018. Genetic identification of macroalgal species on Japanese tsunami marine debris and genetic comparisons with their wild populations. Mar. Poll. Bull. 132: 74-81.

Harp, D. 2002. Current Technology of Chlorine Analysis for Water and Wastewater. Technical Information Series - Booklet No. 17. Hach, USA.

Hégaret, H., S.E. Shumway, G.H. Wikfors, S. Pate and J. Burkholder. 2008. Potential transport of harmful algae via relocation of bivalve molluscs. Mar. Ecol. Prog. Ser. 361: 169-179.

Hommersand, M.H. and S. Fredericq. 1990. Sexual reproduction and cystocarp development. In: (K.M. Cole and R.G. Sheath, eds) Biology of the red algae. Cambridge Univ Press, Cambridge. pp. 305-345.
Hua, G. and D.A. Reckhow. 2007. Comparison of disinfection byproduct formation from chlorine and alternative disinfectants. Water Res. 41: 1667-1678.

Huang, W. and Y. Fujita. 1997. Callus induction and thallus regeneration in some species of red algae. Phycol. Res. 45: 105-111.

Kientz, B., M. Thabard, S.M. Cragg, J. Pope and C. Hellio. 2011. A new method for removing microflora from macroalgal surfaces: an important step for natural product discovery. Bot. Mar. 54: 457-469.

Lacoursière-Roussel, A., D.G. Bock, M.E. Cristescu, F. Guichard and C.W. McKindsey. 2016. Effect of shipping traffic on biofouling invasion success at population and community levels. Biol. Invasions 18: 3681-3695.

Liu, F. and S.J. Pang. 2010. Stress tolerance and antioxidant enzymatic activities in the metabolisms of the reactive oxygen species in two intertidal red algae Grateloupia turuturu and Palmaria palmata. J. Expt. Mar. Biol. Ecol. 382: 82-87.

Macroalgal Herbarium Consortium. 2018. www.macroalgae.org (accessed 17 February 2019).

Maine Department of Marine Resources. 2019. https://www.maine. gov/dmr/laws-regulations/regulations/documents/Chapter24_08212018_.pdf (accessed 15 February 2019).

Marston, M. and M. Villalard-Bohnsack. 2002. Genetic variability and potential sources of Grateloupia doryphora (Halymeniaceae, Rhodophyta), an invasive species in Rhode Island Waters (USA). J. Phycol. 38: 649-658.

Mathieson, A.C., C.J. Dawes, J. Pederson, R.A. Gladych and J.T. Carlton. 2008. The Asian red seaweed Grateloupia turuturu (Rhodophyta) invades the Gulf of Maine. Biol. Invasions 10: 985-988.

Medina, F.J., V. Flores, A.V. Gonzalez and B. Santelices. 2015. Coalescence increases abiotic stress tolerance in sporelings of Mazzaella laminarioides (Gigartinales, Rhodophyta). J. Appl. Phycol. 27: 1593-1598.

Nyberg, C.D. and I. Wallentinus. 2005. Can species traits be used to predict marine macroalgal introductions? Biol. Invasions 7: 265-279.

Occidental Chemical Corporation. 2014. OxyChem Sodium Hypochlorite Handbook. Occidental Chemical Corporation, Dallas.

Odom, R.L. and L.J. Walters. 2015. Chemical eradication methods for aquarium strains of Chaetomorpha. J. Aquat. Plant. Manag. 53: 22-27.

OIE. 2009. Manual of diagnostic tests for aquatic animals. World Organization for Animal Health (OIE), Paris.

Packie, R., H. Hidu and M.S. Richmond. 1976. The suitability of Maine waters for culturing American and European Oysters Crassostrea virginica and Ostrea edulis L. Maine Sea Grant Technical Report TR-10-76.

Pignata, C., E. Fea, R. Rovere, R. Degan, E. Lorenzi, M. de Ceglia, T. Schilirò and G. Gilli. 2012. Chlorination in a wastewater treatment plant: acute toxicity effects of the effluent and of the recipient water body. Environ. Monit. Assess. 184: 2091-2103.

Rodrigues, D., A.C. Freitas, L. Pereira, T.A.P. Rocha-Santos, M.W. Vasconcelo, M. Roriz, L.M. Rodrìguez-Alcalá, A.M.P. Gomes and A.C. Duarte. 2015. Chemical composition of red, brown and green macroalgae from Buarcos bay in Central West Coast of Portugal. Food Chem. 183: 197-207.

Russell, A.D. 1999. Bacterial resistance to disinfectants: present knowledge and future problems. J. Hosp. Infect. 43: 57-68. 
Saunders, G.W. and R.D. Withall. 2006. Collections of the invasive species Grateloupia turuturu (Halymeniales, Rhodophyta) from Tasmania, Australia. Phycologia 45: 711-714.

Shams El Din, A.M., R.A. Arian and A.A. Hammond. 2000. On the chlorination of seawater. Desalination 129: 53-62.

Shao, K., J. Wang and B. Zhou. 2004. Production and application of filaments of Grateloupia turuturu (Halymeniaceae, Rhodophyta). J. Appl. Phycol. 16: 431-437.

Simon, C., E. Ar Gall, G. Levavasseur and E. Deslandes. 1999. Effects of short-term variations of salinity and temperature on the photosynthetic response of the red alga Grateloupia doryphora from Brittany (France). Bot. Mar. 42: 437-440.

Simon, C., E. Ar Gall and E. Deslades. 2001. Expansion of the red alga Grateloupia doryphora along the coasts of Brittany (France). Hydrobiologia 443: 23-29.

Steininger, J.M. and C. Pareja. 1996. ORP sensor response in chlorinated water. NSPI Water Chemistry Symposium, Phoenix, Vol. 1.

Timmons, M.B., J.M. Ebeling, F.W. Wheaton, S.T. Summerfelt and B.J. Vinci. 2002. Recirculating aquaculture systems. 2nd edition. Cayuga Aqua Ventures, Ithaca. pp. 1-769.

Verlaque, M., P.M. Brannock, T. Komatsu, M. Villalard-Bohnsack and M. Marston. 2005. The genus Grateloupia C. Agardh (Halymeniaceae, Rhodophyta) in the Thau Lagoon (France, Mediterranean): a case study of marine plurispecific introductions. Phycologia 44: 477-496.

Villalard-Bohnsack, M. and M.M. Harlin. 1997. The appearance of Grateloupia doryphora (Halymeniaceae, Rhodophyta) on the northeast coast of North America. Phycologia 36: 324-328.

Vranken, S., S. Bosch, V. Peña, F. Leliaert, F. Mineur and O. De Clerck. 2018. A risk assessment of aquarium trade introductions of seaweed in European waters. Biol. Invasions 20: 1171-1187.

Whitman Miller, A., I.C. Davidson, M.S. Minton, B. Steves, C.S. Moser, L.A. Drake and G.M. Ruiz. 2018. Evaluation of wetted surface area of commercial ships as biofouling habitat flux to the United States. Biol. Invasions 20: 1977-1990.

Williams, S.L. and S.L. Schoeder. 2004. Eradication of the invasive seaweed Caulerpa taxifolia by chlorine bleach. Mar. Ecol. Prog. Ser. 272: 69-76.

Williams, S., I. Davidson, J. Parsari, G. Ashton, J.T. Carlton, R.E. Crafton, R.E. Fontana, E.D. Grosholz, A. Whitman Miller, G.M. Ruiz and C. Zabin. 2013. Managing multiple vectors for marine invasions in an increasingly connected world. Bioscience 63: 952-966.

Williams, S.L., R.E. Crafton, R.E. Fontana, E.D. Grosholz, G. Ha, J.R. Parsari and C.J. Zabin. 2015. A vector analysis of marine ornamental species in California. Manag. Biol. Invas. 6: 13-29.

Yamada, Y. 1941. Note on some Japanese algae VIII. Sci. Pap. Inst. Algol. Res. Fac. Sci. Hokkaido Imp. Univ. 2: 195-215.

Yoon, H.S., W. Nelson, S.C. Lindstrom, S.M. Boo, C. Pueschel, H. Qiu and B. Bhattacharya. 2016. Rhodophyta. In: (J.M. Archibald, A.G. Simpson and C.H. Slamovits, eds) Handbook of the Protists. Springer, Switzerland. pp. 1-45.

Supplementary Material: The online version of this article offers supplementary material (https://doi.org/10.1515/bot-2018-0104).

\section{Bionotes}

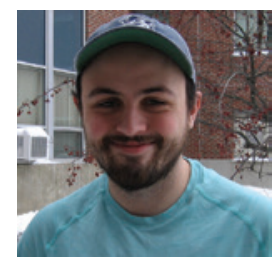

\section{Kyle Capistrant-Fossa}

School of Marine Sciences, University of Maine, 5735 Hitchner Hall, Orono, ME 04469-5735, USA, kyle.capistrantfossa@maine.edu. https://orcid.org/0000-0003-1159-4556

Kyle A. Capistrant-Fossa is a MS student in the School of Marine Sciences at the University of Maine (Orono, ME, USA). He is interested in the effects of climate change on intertidal organisms.

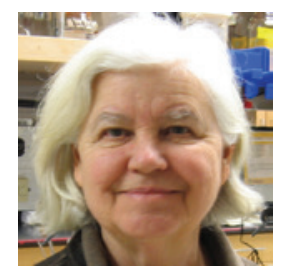

\section{Susan H. Brawley}

School of Marine Sciences, University of Maine, 5735 Hitchner Hall, Orono, ME 04469-5735, USA. https://orcid. org/0000-0002-6444-5290

Susan H. Brawley is Professor of Plant Science in the School of Marine Sciences at the University of Maine (Orono, ME, USA). Her research interests range from ecology to cell biology. 